\title{
36. PHYSICAL PROPERTIES OF VOLCANICLASTIC SEDIMENTS IN THE IZU-BONIN AREA ${ }^{1}$
}

\author{
Kathleen A. Dadey² and Adam Klaus ${ }^{3}$
}

\begin{abstract}
We examine the physical properties of volcaniclastic sediments in the forearc and backarc of the Izu-Bonin arc region. Based on our analyses of these and other deposits in the area, we conclude that, with the possible exception of pumice-rich material, unlithified volcaniclastics behave much like detrital deep-sea sediments. In contrast, lithified volcaniclastic sediments display unique physical properties, such as higher electrical resistivity and velocity than expected from porosity values. The primary cause of these phenomena is a lack of interconnectedness of the pore spaces and cementation of the volcaniclastic particles.
\end{abstract}

\section{INTRODUCTION}

Volcaniclastic sediments are present in all the ocean basins as disseminated ash, thin beds, and thicker deposits (Lisitzin, 1972). Based on the concentration of active subaerial and submarine volcanoes around the globe, the volume of material ejected, and the distance the material travels (Lisitzin, 1972), it is clear that volcanogenic sediments are an important component of deep-sea deposits. Most studies of volcaniclastic sediments to date have concentrated on the identification of depositional processes (Fisher, 1984, and references therein) and the lithologic characteristics of the deposits, such as grain size (McCoy and Cornell, 1990), shape (Wohletz, 1983), stratigraphy (Carey and Sigurdsson, 1978), chemistry and petrology (Lopatin, 1979), and thickness and volume of the deposits (Pyle, 1989).

Very little work, however, has been devoted to the physical and mechanical properties of volcaniclastic sediments, despite the fact that physical properties have been used in the interpretation of depositional and postdepositional processes (Jarrard and Arthur, 1989; Hill and Marsters, 1990); as stratigraphic tools, and as aids to seismic interpretations (Pittenger et al., 1989). Few studies have examined physical property trends in volcaniclastic sediments (Bouma and Moore, 1975; Carlson and Christensen, 1977; Carlson et al., 1980; Carlson, 1981), and none of these investigations examined the entire suite of physical property data; instead, most concentrated on velocity and density analyses. In addition, these previous studies were hampered by incomplete recovery of sections and samples of uncertain quality.

In this investigation, we employ a comprehensive data set of physical properties from sediments recovered during Ocean Drilling Program (ODP) Leg 126 in the Izu-Bonin Arc region to document the physical and mechanical properties of volcaniclastic sediments, as well as the processes that modify these properties. Core recovery in the Leg 126 holes examined in this study averages approximately $66 \%$, with most holes exceeding $70 \%$. Most of the cores analyzed in this study were retrieved using either advanced hydraulic piston coring (APC) or extended core barrel (XCB) drilling techniques. Consequently, these samples represent some of the longest, most continuous, and least disturbed sections of volcaniclastic deposits ever studied. Our primary goals in this study are to define the variations and trends of physical properties in volcaniclastic sediments and to gain insights as to how postdepositional processes affect these properties. We examine sites in the forearc basin (Sites 787, 792,

\footnotetext{
'Taylor, B., Fujioka, K., et al., 1992. Proc. ODP, Sci. Results, 126: College Station, TX (Ocean Drilling Program).

${ }^{2}$ Graduate School of Oceanography, University of Rhode Island, Narragansett, RI 02882, U.S.A.

${ }^{3}$ Department of Geology and Geophysics, University of Hawaii, 2525 Correa Road, Honolulu, HI 96822, U.S.A. (present address: Ocean Research Institute, University of Tokyo, 1-15-1 Minamidai, Nakano, Tokyo 164, Japan).
}

and 793) and in Sumisu Rift, an actively-rifting backarc basin (Sites 788, 790, and 791; Fig. 1) and investigate downhole trends and interrelationships between porosity, wet-bulk density, dry-bulk density, water content, grain density, electrical resistivity, and compressional wave velocity. In addition, we present the results of a preliminary study of the consolidation/compression behavior of volcaniclastic-rich samples from Site 790.

\section{STUDY AREA}

The study area of this investigation comprises the forearc region of the Izu-Bonin Arc and the currently rifting backarc basin (Sumisu Rift). Sedimentary deposits in the area are dominated by volcanogenic material derived from the active arc, although numerous intervals of nannofossil-rich sediments, resulting from pelagic deposition during periods of volcanic quiescence exist (Taylor, Fujioka, et al., 1990). Six sites are examined, three in the forearc basins and three in the Sumisu Rift regions (Fig. 1).

Site 788 is on the top of the eastern margin of Sumisu Rift, between active arc volcanoes Sumisu Jima ( $58 \mathrm{~km}$ to the north) and Tori Shima ( $55 \mathrm{~km}$ to the south-southeast). Sediments are dominated by volcaniclastic debris and include deposits from four major eruptions within the past 4 m.y. Hemipelagic deposits accumulated during volcanic quiescent periods in the early Pliocene. Sites 790 and 791 are located within Sumisu Rift, approximately $2.4 \mathrm{~km}$ apart. Lithologic Unit I at both sites is characterized by an abundance of volcanogenic material. Pumice, often granule-sized or larger, is common. Unit II is predominantly nannofossil clay (Site 790) and claystone (Site 791; Table 1).

Site 787, in the forearc basin, is located in the axis of Aoga Shima Canyon, about $95 \mathrm{~km}$ east of the arc volcano Aoga Shima. Lithologic Units I and II are unconsolidated and Units III and IV are lithified (Table 1). All sediments are mixtures of volcanogenic and biogenic material. Approximately $1 \mathrm{~km}$ of sediment has been eroded by channel processes at this site. Site 792 is located about $60 \mathrm{~km}$ east of the arc volcano Aoga Shima. It lies upslope from a fork in Aoga Shima Canyon. Volcanic input to the site was high before $27 \mathrm{Ma}$ (lithologic Unit IV), minimal between 27 and $13 \mathrm{Ma}$ (Unit III), and moderate to increasing from 13 Ma to the present (Units I and II). Site 793, in the center of the forearc basin, is approximately $75 \mathrm{~km}$ east of the arc. between the volcanoes Sumisu Jima and Tori Shima. Unit V consists primarily of volcaniclastic material, deposited by sediment gravity flows. The deposition was of clays and biogenic material in Unit IV suggests a volcanic quiescent period at this time. Volcaniclastic sediments are common in Units I and III (Unit II is a diabase sill).

Hemipelagic nannofossil-rich and nannofossil-dominated intervals were recovered at all sites on Leg 126 (Table 1). We examined these sediments, however, only when they contrasted with the properties of the over- and underlying volcaniclastic sequences. Where sediment core descriptions indicate the presence of both volcaniclas- 


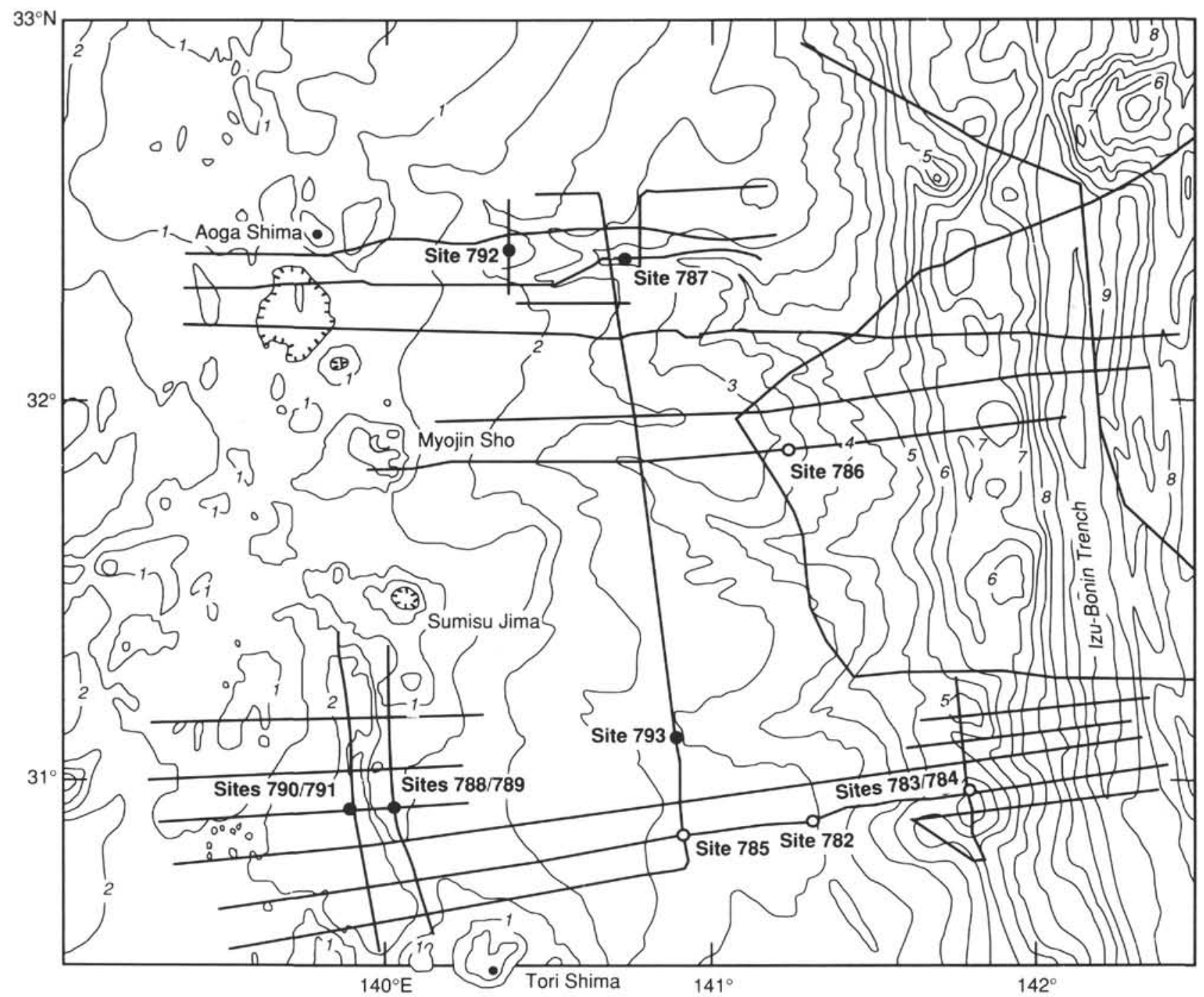

Figure 1. Map of the Izu-Bonin Arc region showing the locations of the six sites investigated.

tic and biogenic (hemipelagic) lithologies (e.g., as a result of mixing by burrowing infauna), we used the carbonate contents of the samples to differentiate between the two. Samples containing $<5 \% \mathrm{CaCO}_{3}$ are considered volcaniclastic. This classification conforms with that in Taylor, Fujioka, et al. (1990, "Explanatory Notes" chapter) and provides reasonable certainty that the samples we include in the data set are volcaniclastic in origin. Unless specified, all samples/sediments discussed in this manuscript refer to volcanogenic material.

\section{METHODS}

Porosity $(\phi)$, wet-bulk density $\left(\rho_{w}\right)$, dry-bulk density $\left(\rho_{\mathrm{f}}\right)$, water content (wc), and grain density $\left(\rho_{\mathrm{g}}\right)$ were calculated from measurements of sample weights and volumes. Weights were determined on a Scitech electronic balance to a precision of $\pm 0.01 \mathrm{~g}$. Volume measurements were obtained using a Quantachrome Penta-Pycnometer, which uses Archimedes' principle of volume displacement and helium gas to determine the sample volume. (For more details of these procedures, see "Explanatory Notes" chapter in Taylor, Fujioka, et al., 1990, and Dadey et al., this volume.)

Three 6-cm long samples were cut from unsplit (APC) core sections from Hole 790A at depths of 1.52,11.8, and 21.27 mbsf. These samples were capped, sealed, and refrigerated until analyzed for consolidation/compression characteristics. Standard incremental-loading odo- meters were used during consolidation testing; loads were increased approximately every $24 \mathrm{hr}$, the average period required for complete dissipation of excess pore pressures (e.g., Bryant et al., 1981). The resulting data are expressed as void ratio (e) vs. logarithm of effective stress $\left(\sigma^{\prime}\right)$. Preconsolidation stress, defined as the stress to which the sediment was consolidated in situ $\left(\sigma_{\mathrm{c}}{ }^{\prime}\right)$, was determined with the Casagrande (1936) graphical technique. The overconsolidation ratio (OCR) is calculated as the preconsolidation stress divided by the overburden stress. In soil mechanics terminology, an OCR of 1.0 signifies that the sample is normally consolidated, that is, presently experiencing the greatest overburden stress ever imposed. An OCR greater than unity (overconsolidation) implies that the overburden stress was greater in the past; this situation is generally caused by removal of overburden by erosion. The compressibility index of each sample $\left(\mathrm{C}_{\mathrm{c}}\right)$ was calculated as the slope of the in situ portion of the void ratio (e) vs. $\log \sigma^{\prime}$ curve (i.e., that part where $\sigma^{\prime}>\sigma_{c}^{\prime}$ ).

\section{POSTDEPOSITIONAL PROCESSES}

Two distinct, but not mutually exclusive, postdepositional processes most likely influence the physical properties of the sediments in the study area. These processes are (1) consolidation/compaction and (2) diagenetic changes. Consolidation, resulting from the increased weight of overlying material (overburden) during normal 
Table 1. Primary lithologies of Leg 126 cores in this study.

\begin{tabular}{|c|c|c|c|}
\hline Site & Unit & Primary lithologies & Interpretation \\
\hline \multirow[t]{4}{*}{787} & & Pumiceous and scoriaceous sandy gravel & Volcanic \\
\hline & II & $\begin{array}{l}\text { Nannofossil ooze, nannofossil-rich clays } \\
\text { Nannofossil-rich claystone, claystone }\end{array}$ & Hemipelagic \\
\hline & IVA & $\begin{array}{l}\text { Nannofossil-nch claystone, claystone } \\
\text { Sandstone, siltstone, vitric silty claystone }\end{array}$ & $\begin{array}{l}\text { Hemipelagıc } \\
\text { Hemipelagic }\end{array}$ \\
\hline & ivB & Pebble-rich sandstone, silty claystone & Hemipelagic \\
\hline \multirow[t]{4}{*}{788} & IA & Pumiceous sandy gravel, vitric sands & Volcanic \\
\hline & IB & Pumiceous sandy pebble conglomerate & Volcanic \\
\hline & IIA & Nannofossil-rich claystone, vitric silty claystone & Hemipelagic \\
\hline & & Pumiceous conglomerate, vitric sandstone & Volcanic \\
\hline \multirow[t]{2}{*}{790} & i & Vitric silt, vitric sand, pumiceous gravel & Volcanic \\
\hline & il & Nannofossil clay, nannofossil-rich clay & Hemipelagic \\
\hline \multirow[t]{2}{*}{791} & I & Pumiceous gravel, pumiceous pebbly sand & Volcanic \\
\hline & iI & Nannofossil-rich claystone, nannofossil claystone & Hemipelagic \\
\hline \multirow[t]{5}{*}{792} & I & Nannofossil-rich vitric silty clay, nannofossil-rich clayey silt & Hemipelagic \\
\hline & II & Sandy mudstone, muddy sandstone & Hemipelagic \\
\hline & III & Nannofossil-rich claystone, nannofossil claystone & Hemipelagic \\
\hline & IV & Vitric sandstone, volcanic sandy conglomerate & Volcanic \\
\hline & v & Altered volcanic sandstone & Volcanic \\
\hline \multirow[t]{6}{*}{793} & IA & Pumiceous gravel, sandy gravel & Volcanic \\
\hline & IB & Pumiceous sand, vitric sand & Volcanic \\
\hline & III & Nannofossil-rich silty claystone, silty claystone & Hemipelagic \\
\hline & IV & Claystone, nannofossil claystone & Hemipelagic \\
\hline & $\mathrm{v}$ & Vitric sandstone, pumiceous sandstone & Volcanic \\
\hline & VI & Volcanic breccia & Volcanic \\
\hline
\end{tabular}

deposition, is related to the depth of the sample. Phenomena associated with the consolidation process include expulsion of pore fluid, reductions in porosity and water content, increases in bulk density, and concomitant increases in sonic velocity and resistivity. Postdepositional diagenetic effects are especially important in this unstable volcanic material. Diagenetic mineral alteration, such as the formation of clay minerals and zeolites from original volcanic material, are of particular importance. Cementation, resulting from mineral formation and/or chemical precipitation, has the effect of increasing sediment rigidity though not necessarily reducing porosity. These diagenetic effects are superimposed on physical property changes that originate from increased consolidation with depth. In some cases, diagenetic effects overwhelm those from consolidation and control the physical property variations. Chemical reactions associated with diagenesis are primarily a function of time not depth of burial. Consequently, these two postdepositional processes proceed at different rates and are most dependent on age (diagenetic effects) or depth (consolidation effects).

We define the sedimentary sequences at Sites 791 and 792 as representative of the majority of volcaniclastic deposits recovered in the Izu-Bonin area; together, they comprise a nearly continuous, 800 -m-thick section of volcaniclastic material that provides an excellent opportunity for studying the effects of postdepositional processes on these sediments. The compressional wave velocity at Site 791 is generally greater than that observed in sediments of the same age at Site 792, at least in sediments younger than approximately 1.0 Ma. This difference is likely the results of the greater depths and more advanced consolidation for equivalent ages at Site 791 (Fig. 2A). The effects of diagenetic changes become dominant below approximately 150-200 m below seafloor (mbsf), as evidenced by higher sonic velocity values at Site 792 for the same depths as at Site 791 (Fig. 2B). Cementation of the sediments during diagenesis most likely is controlling the velocity of these older sediments at Site 792. The sharp decrease in volcanic glass and concurrent increases in palagonite, glauconite, and zeolites (Taylor, Fujioka, et al., 1990) coincident with a velocity peak at $250 \mathrm{mbsf}$ (Fig. 2B) support the idea that cementation has a dominant effect on the velocity of these sediments.

Plots of velocity vs. porosity are particularly useful for distinguishing between the state of consolidation vs. the extent of diagenesis or cementation. We examine the velocity/porosity relations in the context of two limiting equations. The Wood (1941) equation is used to represent the behavior of high porosity, unconsolidated sedimentary deposits. Because such mixtures are controlled primarily by properties of the pore fluid, intrinsic differences in individual sediment grain elastic moduli have minimal effect on the behavior of the material. Consequently, the shear modulus is assumed to be zero and the bulk modulus is equal to the geometric average of the bulk moduli
A
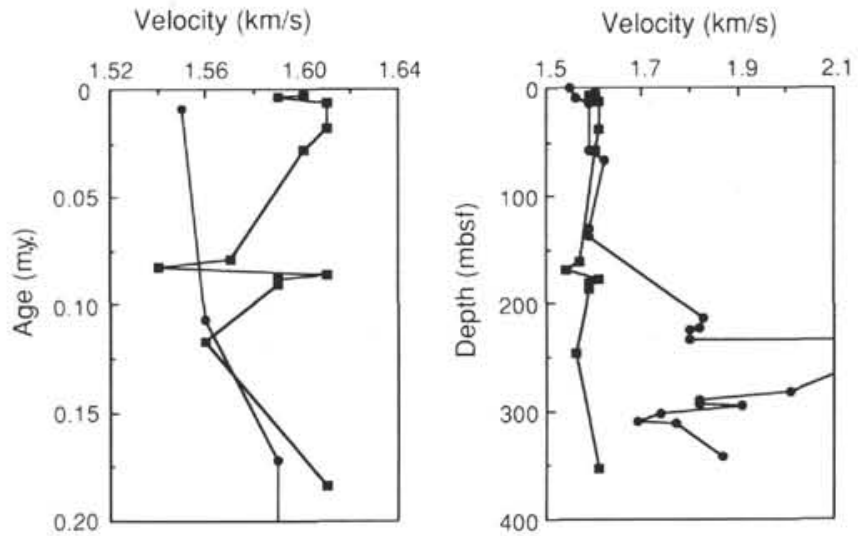

Figure 2. A. Compressional wave velocity vs. age, Sites 791 (filled squares) and 792 (filled circles). Values at Site 791 are up to $0.06 \mathrm{~km} / \mathrm{s}$ faster than those at Site 792 , to approximately $0.12 \mathrm{~m}$.y., below which, values at both sites are similar. B. Compressional wave velocity vs. depth, Sites 791 (filled squares) and 792 (filled circles). Values at both sites are similar to depths of approximately 140 mbsf (note the different velocity scales in Figs. 2A and 2B, however). Below this depth, velocity values at Site 792 are significantly higher.

of grains and fluid. The assumption of a zero shear modulus, however, has been shown to be less valid as porosity decreases and grain interaction increases (Hamilton and Bachman, 1982). The other limit on velocity/porosity behavior is shown by the Wyllie equation (Wyllie et al., 1956). Because the compressional wave velocity of lithified rocks is influenced by grain mineralogy and the extent to which the grains are cemented into a rigid framework (Osgushwitz, 1985; Wilkens et al., 1986), an empirical relationship has been developed to describe their behavior. The Wyllie equation uses grain and fluid velocities, rather than bulk moduli to describe the velocity/porosity relation. This equation most closely approximates the behavior of lithified sedimentary rocks. Its validity is usually restricted to sediments with porosities $<30 \%$.

In general, increasing consolidation tends to increase velocity through a decrease in porosity (i.e., movement parallel to the Wood line). Cementation, on the other hand, effects a velocity increase through increased rigidity of the sediment structure with little or no reduction in porosity (i.e., vertical movement on the velocity vs. porosity plot). When one examines a plot of all velocity vs. porosity measurements of Leg 126 sediments (Fig. 3), several patterns emerge. Only samples within the dashed lines conform to the Wood (1941) equation. The general trend is a high porosity $(>50 \%-55 \%)$ zone in which velocity values increase without a significant decrease in porosity; lower porosity samples tend to cluster around the Wyllie line. These data suggest that cementation plays a significant role in the lithification of these deposits. Samples that have velocity values significantly above the Wyllie line have most certainly experienced significant amounts of cementation (for example, samples from Sites 788 and 793; Fig. 3). The transition from unconsolidated sediment to lithified rock is particularly well illustrated at Site 792 (Fig. 4) in which progressively older units have higher velocities as the result of both increased consolidation (porosity decreases) and cementation (high velocity values at high porosities).

We also use velocity-porosity relations to illustrate differences in the behavior of volcaniclastic and biogenic sediments, particularly at sites in the backarc region. Volcaniclastic sediments from both Sites 790 and 791 display similar velocity-porosity relationships, despite the fact that some of the Site 791 samples were recovered from depths about three times greater than equivalent age samples from Site 790. This relationship suggests that depth (i.e., increased consolidation) 


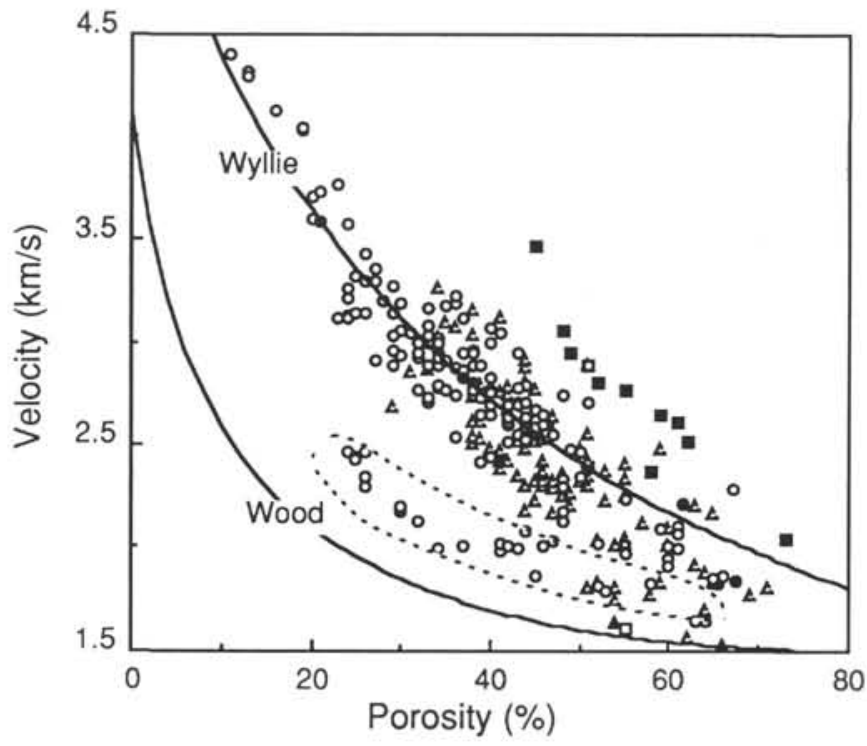

Figure 3 . Velocity vs. porosity at all sites. Filled circles $=$ Site 787 , filled squares $=$ Site 788 , filled triangles $=$ Site 790 , open squares $=$ Site 791, open triangles $=$ Site 792, and open circles $=$ Site 793. The majority of values at all sites cluster near the Wyllie empirical line; samples within the dashed line are those which parallel the Wood line. Numerous values at Site 793 fall above the Wyllie line; nearly all the Site 788 points are significantly higher than the Wyllie line.

does not significantly affect velocities in these young $(<1.1$ m.y.) samples. Hemipelagic nannofossil claystones (Unit II) from Site 790 actually show lower average velocities and generally higher porosities than either the shallower Site 790 volcaniclastic sediments (Unit I) or Site 791 volcaniclastic samples. Samples from the hemipelagic unit at Site 791 show relatively higher velocities, but also generally lower porosity values (Fig. 5). These data suggest that consolidation is the dominant influence in the velocity increase observed in the hemipelagic sediments, whereas cementation is of primary importance in the volcaniclastic units.

An extreme example of the anomalous physical properties of cemented volcaniclastic sediments is observed in the pumice conglomerates recovered at Sites 788, 792, and 793. Our analyses of these deposits suggest that they have significantly different properties than other deep-sea sediments, particularly with respect to conduction of electrical and sonic energy. These conglomerates are composed of large grains of high porosity pumice welded to form an indurated rock. The high porosity is essentially frozen into the pumice particles (i.e., intragranular porosity) and thus may be termed "dead end" porosity. Although the sediment is very porous, the structure is relatively impermeable to movement of fluid, dissolved chemical species, and electrical energy because many of the pore spaces are isolated,. Sonic energy, on the other hand, is conducted through the solid particles and may be much higher than implied by porosity measurements if the majority of particles are in physical contact. For example, a comparison of the velocity vs. porosity relationship of Site 788 sediments with those of Sites 790 and 791 suggests that the majority of the increase in velocity at this site is a result of cementation (Fig. 3). We infer this result both from the location of the Site 788 data relative to that of Sites 790 and 791 and from the steeper slope of the velocity vs. porosity relationship.

We also undertook a direct, albeit very preliminary, investigation of the consolidation/compression behavior of pumice-rich samples from Site 790. Although three samples are too small a number on which to base firm conclusions, we present the following results and theories as preliminary, with the intention of generating discussion and further investigation.

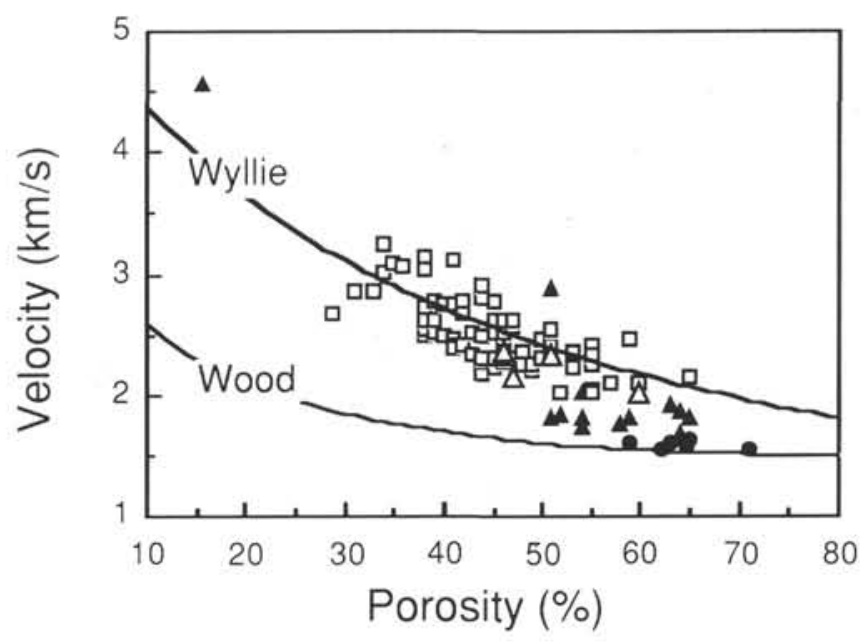

Figure 4. Velocity vs. porosity at Site 792 (only volcaniclastic sediments are included). Filled circles $=$ Unit I, filled triangles = Unit II, open squares = Unit IV , and open triangles $=$ Unit V. In general, velocity values increase from Units I through V. Exceptions are found in several samples in Unit V.

All three samples examined displayed significant overconsolidation, even when one allows for imprecision and errors associated with the calculation of preconsolidation and overburden stresses (Table 2). There is no evidence of erosion, or any other mass wasting, however, at Site 790 (Taylor, Fujioka, et al., 1990). Furthermore, OCRs decrease with depth as a result of increasing overburden but also as a result of decreasing preconsolidation stresses with depth. This situation is the opposite of what would be expected for normally consolidating sediments, which by definition display increasing preconsolidation stress with depth. In addition, the compressibility index of the sediments increases with depth (Table 2). Examination of core photos, sediment descriptions, and smear slide analyses (Taylor, Fujioka, et al., 1990) indicates that all three samples are composed primarily of pumice-rich vitric silt. Only the shallowest sample (1.52 mbsf) contains any appreciable amount of clay-sized material $(10 \%-20 \%)$, clay minerals $(10 \%)$, and accessory minerals (up to $25 \%$ oxide). These components, however, might be expected to increase the compressibility, rather than decrease it. It appears that the volcaniclastic fraction of these samples control their compressibility.

We suggest that the decrease in preconsolidation stress and increase in compressibility in these pumice-rich samples is the result of crushing of the grain contacts and consequent rounding of the particles with depth. In the shallow layers, the sediment has a very high resistance to compression because pumice grains are angular, very irregular, and so may lock in a quasi-rigid framework. This is manifest in both the low compressibility index and the relatively high preconsolidation stress. These sediments represent an extreme example of apparent overconsolidation that has been observed in the top 2-4 m of deposits throughout the world ocean (e.g., Bryant et al., 1981). The OCRs measured in these layers exceed unity as a result of the high inherent strength of the sediment relative to the low overburden stresses. In most of these deposits, weak physicochemical bonds between fine grained particles are the source of this strength. We think that interlocking between the sharp, angular volcaniclastic particles in our samples generates a rigid, strong structure that resists consolidation. Support for this idea includes the similar porosity values measured in the volcaniclastic units at Sites 790 and 791, although this layer is approximately three times as thick at Site 791. Increasing compressibility and decreasing preconsolidation stress with depth (and overburden) result from gradual rounding of the particles through crushing and increased ease of particle movement.

Plots of the ratio of shear strength to overburden stress supply further evidence for the generation of a strong framework. The 


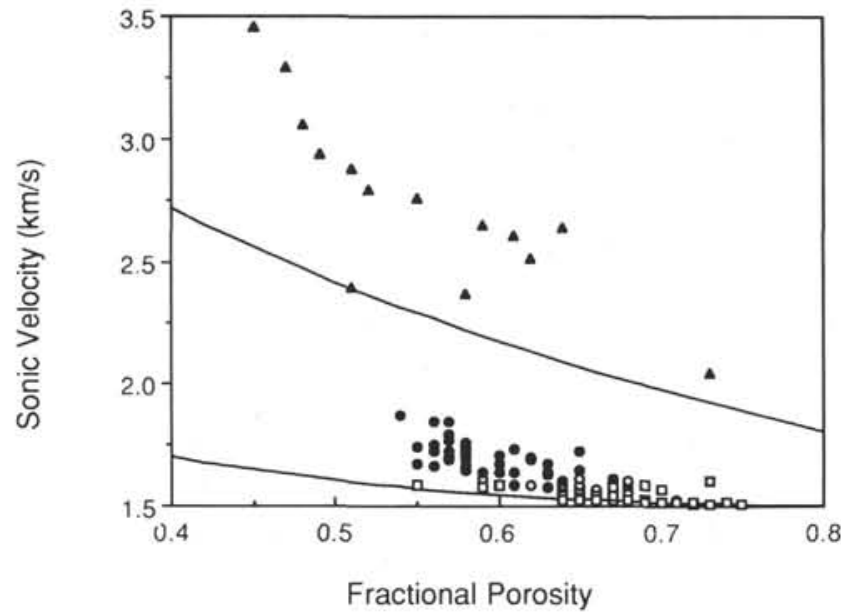

Figure 5. Velocity vs. porosity of volcaniclastic and hemipelagic units at backarc sites; only volcanic units at Site 788 are included. Filled triangles = Site 788 volcaniclastic, open squares $=$ Site 790 volcaniclastic, filled squares $=$ Site 790 hemipelagic, filled circles $=$ Site 791 volcaniclastic, and open circles = Site 791 hemipelagic. Despite the fact that samples from all sites are from similar depths, velocity values are significantly higher, and porosities generally lower, at Site 788 than at Sites 790 or 791.

Table 2. Consolidation characteristics of Hole 790A samples.

\begin{tabular}{cccccc}
\hline $\begin{array}{c}\text { Core, section, } \\
\text { interval }(\mathrm{cm})\end{array}$ & $\begin{array}{c}\text { Depth } \\
\text { (mbs) }\end{array}$ & $\begin{array}{c}\text { Overburden } \\
\text { stress } \\
(\mathrm{kPa})\end{array}$ & $\begin{array}{c}\text { Reconsolidation } \\
\text { stress } \\
(\mathrm{kPa})\end{array}$ & OCR & $\begin{array}{c}\text { Compression } \\
\text { index }\end{array}$ \\
\hline 126-790A- & & & & & \\
$1 \mathrm{H}-2,0-5$ & $1.50-1.55$ & 0.78 & 69 & 8.8 & 0.1 \\
$2 \mathrm{H}-2,145-150$ & $11.75-11.80$ & 6.06 & 49 & 8.1 & 0.15 \\
$3 \mathrm{H}-2,145-150$ & $21.25-21.30$ & 11.69 & 43 & 3.7 & 0.18 \\
\hline
\end{tabular}

Note: $\mathrm{OCR}=$ overconsolidation ratio.

parameter $\mathrm{S}_{\mathrm{u}} / \sigma_{\mathrm{b}}{ }^{\prime}$, the ratio of shear strength to overburden stress, has been used as a proxy of the stress state in deposits for which consolidation analyses are not available. Values between 0.2 and 0.4 are indicative of normally consolidated sediments (Bjerrum, 1961; Skempton, 1970). Ratios above 0.4 suggest overconsolidation. Sediments above about 150 mbsf at both Sites 790 and 791 indicate an overconsolidated state (Fig. 6A). In reality, however, probably both preconsolidation stress and shear strength are measures of the high inherent strength of these sediments. Although $\mathrm{S}_{\mathrm{u}} / \sigma_{0}{ }^{\prime}$ ratios in the shallowest samples at 792 and 793 are much higher than those observed at 790 and 791 , samples at 792 and 793 reach the normally consolidated zone at much shallower depths (approximately 70-80 mbsf). This result implies that particle angularity and interlocking at Sites 792 and 793 are less important, probably as a result of the lower pumice content in the latter deposits.

Another parameter that can be used for assessing the relative extent of consolidation vs. cementation is the acoustic index, defined by Wilkens et al. (1990) as

$$
\text { Acoustic Index }=\frac{V_{\text {measured }}}{V_{\text {Wyllie }}}-\frac{V_{\text {Wood }}}{V_{\text {Wood }}},
$$

in which $V_{\text {Wood }}$ and $V_{\text {Wyllie }}$ are velocity values calculated from the Wood (1941) and Wyllie et al. (1956) equations, respectively, for the porosity of the measured sample. Higher values are generally indicative of a greater amount of cementation. When plotted vs. depth, this parameter provides some idea of the relative degree of consolidation/cementation with depth. Differences in the acoustic indexes of the backarc sites are strong evidence of diagenetic cementation at Site 788. For example, the acoustic indexes of Site 791 samples are an order of magnitude less than those of Site 791 (Fig. 7). The effects of
A
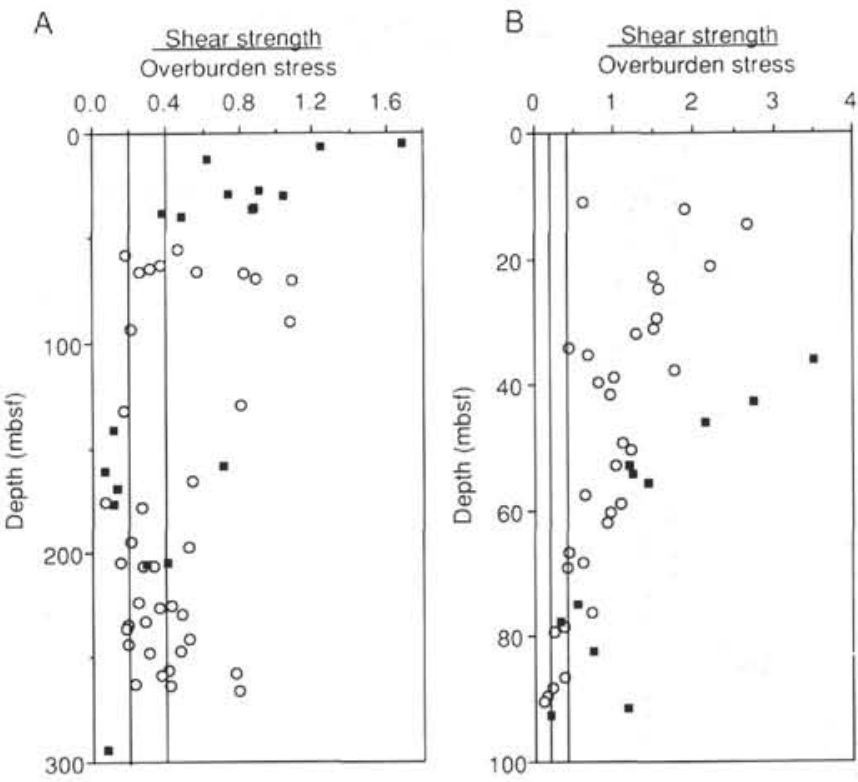

Figure 6. Plots of the ratio of shear strength to overburden stress vs. depth. A. Sites 790 (open circles) and 791 (filled squares). B. Sites 792 (open circles) and 793 (filled squares). The range for normally consolidated sediments $(0.2-0.4)$ is included in each figure.

postdepositional changes are also observed in the plot of dry-bulk density vs. porosity of backarc site samples (Fig. 8). Although virtually all samples from Sites 790 and 791 and most from Site 788 plot along a line with a slope of 2.67 (corresponding to the average grain density of the material), 4 of the 14 samples from Site 788 plot much higher than the others and have a different slope, probably as a result of cementation by alteration products in these samples.

The relative impermeability of high-porosity pumiceous deposits can be demonstrated by examination of the electrical resistivity. Effects caused by differences in pore fluid conductivity are removed by calculating the formation factor (FF), which is the ratio of the bulk sediment resistivity to the resistivity of the pore fluid. The use of this parameter and its relationship to other properties has been discussed in detail by Lovell $(1984,1988)$. Because the solid sediment grains are much more resistive to electrical flow than the pore fluid, FF has long been used as an indicator of the amount of pore space in the deposit (e.g., Archie, 1942). A number of relationships between FF and porosity $(\phi)$ have been developed, generally with the form of the Winsauer et al. (1952) equation:

$$
\mathrm{FF}=\mathrm{C}^{-\mathrm{m}} \text {, }
$$

in which $\mathrm{C}$ and $\mathrm{m}$ are empirically derived constants related to particle composition, and pore and particle shape (e.g., Lovell, 1984). The constant $\mathrm{m}$ is sometimes referred to as the cementation factor and is an estimate of the degree of lithification. Figure 9 is a plot of $\log \mathrm{FF}$ vs. $\log$ porosity for Sites 790,791 , and 792 . The data are plotted with a family of curves corresponding to different values of $\mathrm{C}$ and $\mathrm{m}$. We use a best-fit regression equation to calculate a relationship for all Leg 126 volcaniclastic samples of $\mathrm{FF}=0.022 \phi^{1.25}$. Although there is some disagreement over the form of the equation relating FF and porosity, an inverse relationship is seen between the two parameters. The positive exponent in the equation calculated for the Leg 126 volcaniclastic data set suggests a direct relationship between FF and porosity. We attribute the anomalous behavior of the Leg 126 samples to the lack of interconnectedness of the pore spaces in these volcaniclastic sediments. This lack of interconnectedness is manifest as low conduction (i.e., high resistivity and FF) at high porosity values. 


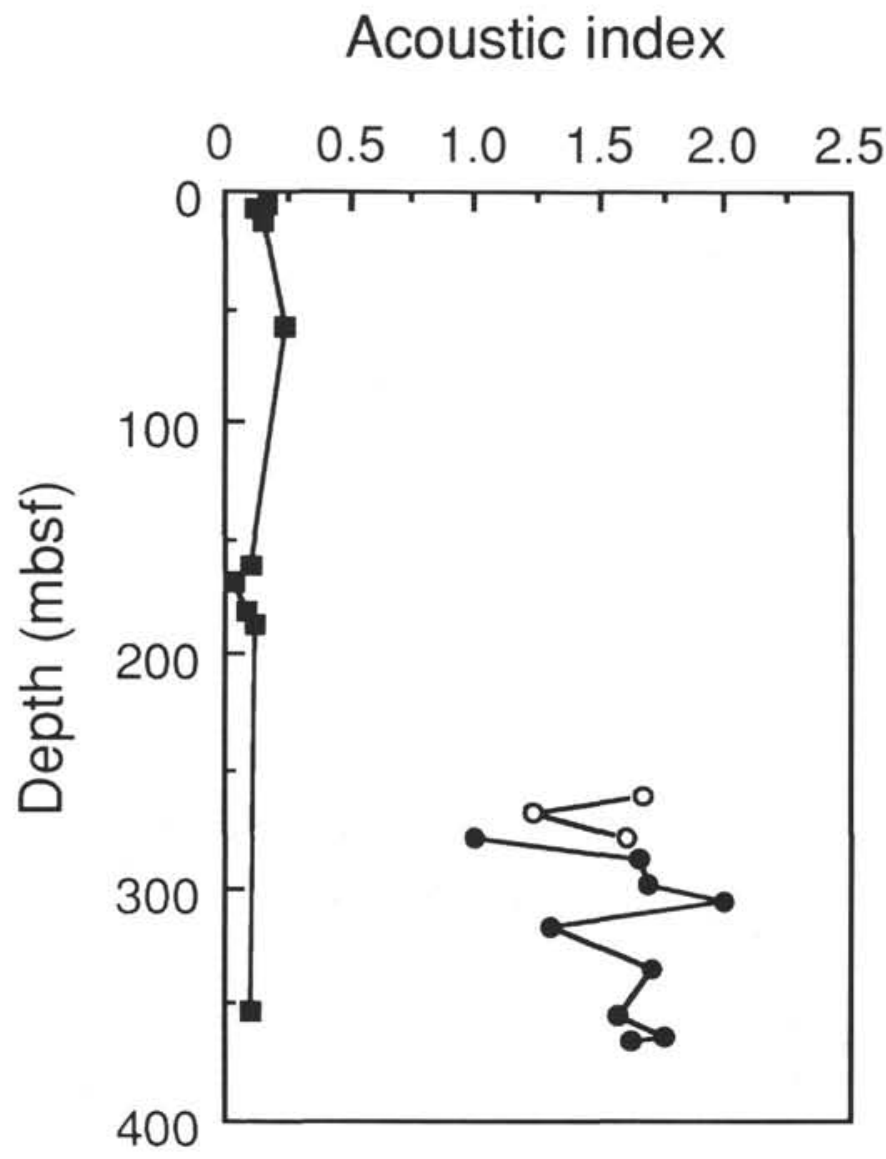

Figure 7. Acoustic index vs. depth at Sites 788 and 791. Open circles $=$ Site 788 Subunit IIA, filled circles $=$ Site 788 Subunit IIB, and filled squares $=$ Site 791 Unit I. Values at Site 791 are low and relatively uniform with depth. Those at Site 788 are nearly four times as high and display a high degree of variation.

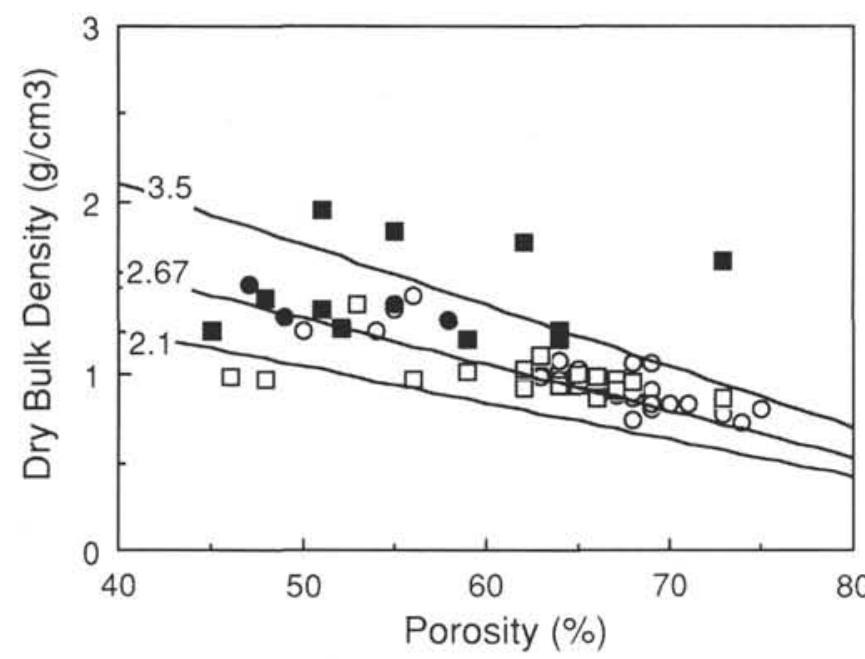

Figure 8 . Dry-bulk density vs. porosity in backarc site samples. Filled circles $=$ Site 788 Subunit IIA, filled squares $=$ Site 788 Subunit IIB, open circles $=$ Site 790, and open squares $=$ Site 791 . Calculated relations for grain densities of $2.1,2.67$, and $3.5 \mathrm{~g} / \mathrm{cm}^{3}$ are included.

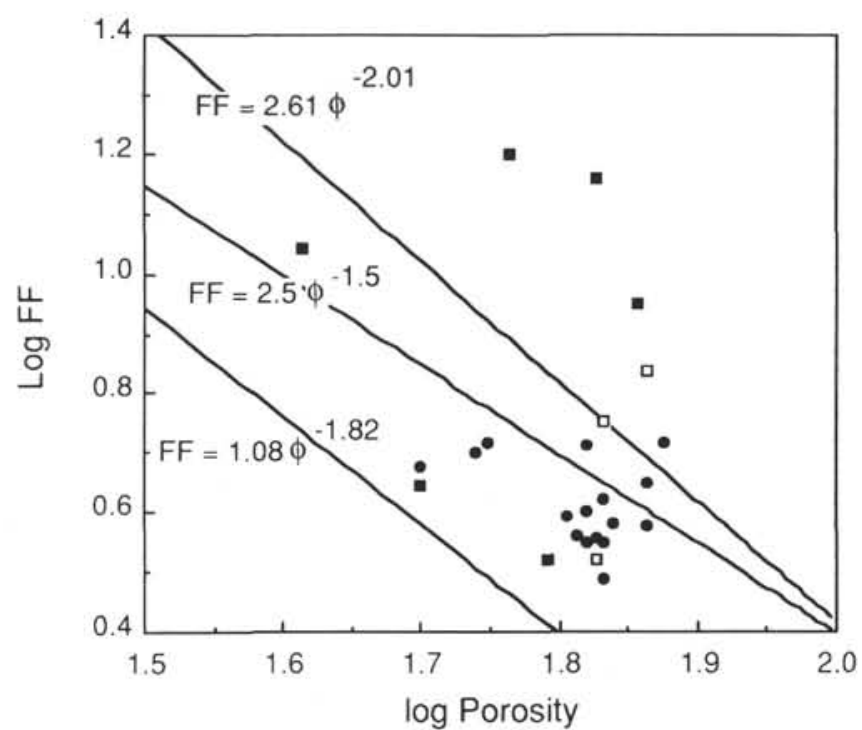

Figure 9. Logarithm formation factor (FF) vs. logarithm porosity for samples from Sites 790, 791, and 792. Filled circles $=$ Site 790, open squares $=$ Site 791 , and filled squares $=$ Site 792. Theoretical curves for various values of C and $\mathrm{m}$ are included.

In the majority of cases, the horizontal (perpendicular to core axis) FF exceeds the vertical (parallel to core axis) FF in these samples (Fig. 10). This relation, the opposite of that reported by Wilkens and Handyside (1985) in calcareous sediments of DSDP Leg 85, implies that conduction perpendicular to bedding is higher than conduction parallel to bedding. Possible causes of this phenomenon are the existence of vertical structures, such as dewatering or deformation cracks that provide vertical conduits for fluid and electrical flow. Such structures were observed deeper in these deposits (Taylor, Fujioka, et al., 1990), but not in the volcaniclastic units investigated here. Instead, it appears that these samples do not develop the same type of preferred grain orientation generally observed in marine sediments, probably because of the relatively large grain size and irregularity of the volcaniclastic particles.

Although most postdepositional diagenetic changes in these volcaniclastic deposits result in increased rigidity and velocity as a result of cementation, we observe the opposite effect. Several samples in Unit V at Site 793 have lower velocity values than expected for their porosities and low acoustic indexes relative to those in the over- and underlying strata (Fig. 11). The majority of these samples are within a zone (approximately $1100-1150 \mathrm{mbsf}$ ) that has experienced a significant degree of postdepositional alteration, primarily formation of smectite minerals (Taylor, Fujioka, et al., 1990). We suspect that the high porosity values in this interval result from high concentrations of smectite minerals. Velocity values in these clay-rich sediments, on the other hand, are generally lower than those in the original(?) over- and underlying volcanic material.

\section{CONCLUSIONS}

Our examination of volcaniclastic deposits in the Izu-Bonin area suggests that, in terms of their physical properties, unlithified volcaniclastic sediments behave much like detrital material, with the possible exception of pumice-rich samples. Pumice-rich deposits exhibit slightly different properties, such as the retention of relatively high porosity values with increasing depth and overburden at Site 791. This difference is 


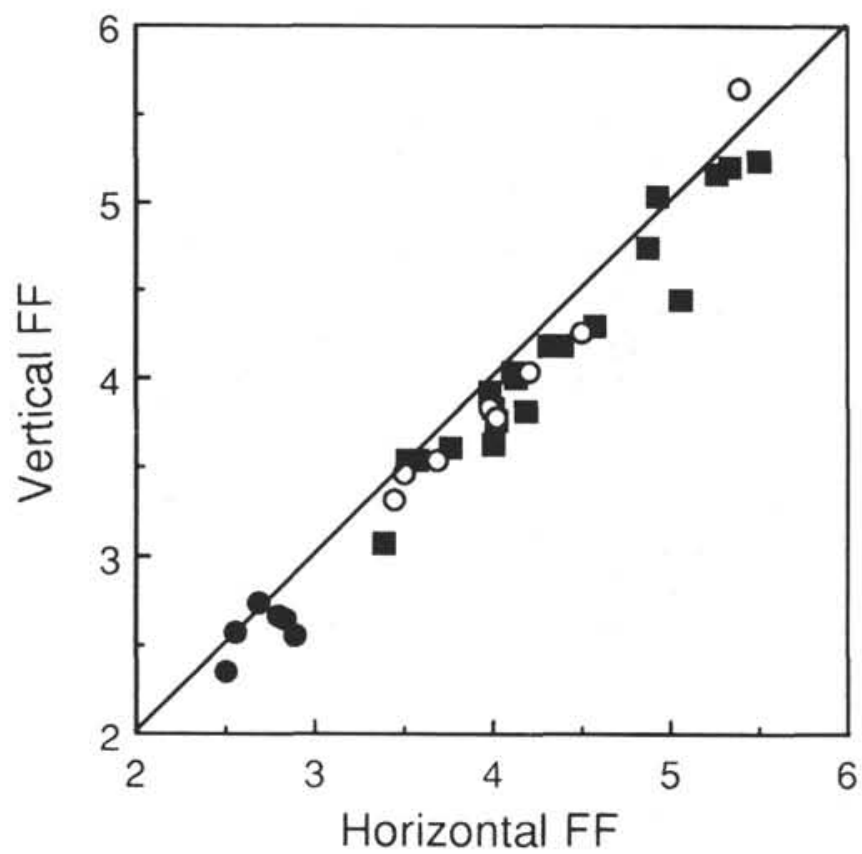

Figure 10. Vertical formation factor (FF) vs. horizontal FF values at Sites 790 , 791, and 792. Filled squares $=$ Site 790, open circles $=$ Site 791, and filled circles $=$ Site 792. A 1:1 correlation line is included for comparison.

probably a result of the large percentage of intragranular pore space in pumice that is trapped during burial. The physical properties of lithified volcaniclastic sediments, however, contrast with those of other rocks. The cause of the majority of these differences is the prominence of "dead end" intraclast porosity (particularly in pumicerich deposits) and postdepositional cementation of the sediment particles. Porosity values are generally quite high in these sediments, but so are velocities and FFs. Velocity values are high because the sonic energy propagates through the solid structure, which because of cementation, is rigid and fairly continuous. Electrical conduction, on the other hand, occurs through the pore fluid. Because so much of the pore space is isolated and not interconnected, the majority of the electrical energy is dissipated through contact with the solid particles, resulting in relatively high resistivity and FF values.

\section{ACKNOWLEDGMENTS}

The skill and enthusiasm of drillers, technicians, and fellow scientists on board the JOIDES Resolution during Leg 126 provided the opportunity and raison d'etre for this study. Roy Wilkens and two anonymous reviewers provided numerous comments and suggestions for improvement. This work was partially funded under NSF grant to K.A.D. and M. Leinen.

\section{REFERENCES}

Archie, G. E., 1942. The electrical resistivity log as an aid in determining some reservoir characteristics. J. Pet. Tech., 5:54-62.

Bjerrum, L., 1961. The effective shear strength parameters of sensitive clays. Proc. 5th Intl. Conf. Soil Mech. and Found. Engr., Paris, 1:23-28.

Bouma, A. H., and Moore, J. C., 1975. Physical properties of deep-sea sediments from the Philippine Sea and Sea of Japan. In Karig, D. E., Ingle, J. C., Jr., et al., Init. Repts. DSDP, 31: Washington (U.S. Govt. Printing Office), 535-568.

Bryant, W. R., Bennett, R. H., and Katherman, C. E., 1981. Shear strength, consolidation, porosity, and permeability of oceanic sediments. In Emiliani, C. (Ed.), The Sea (Vol. 7): New York (Wiley), 1555-1616.

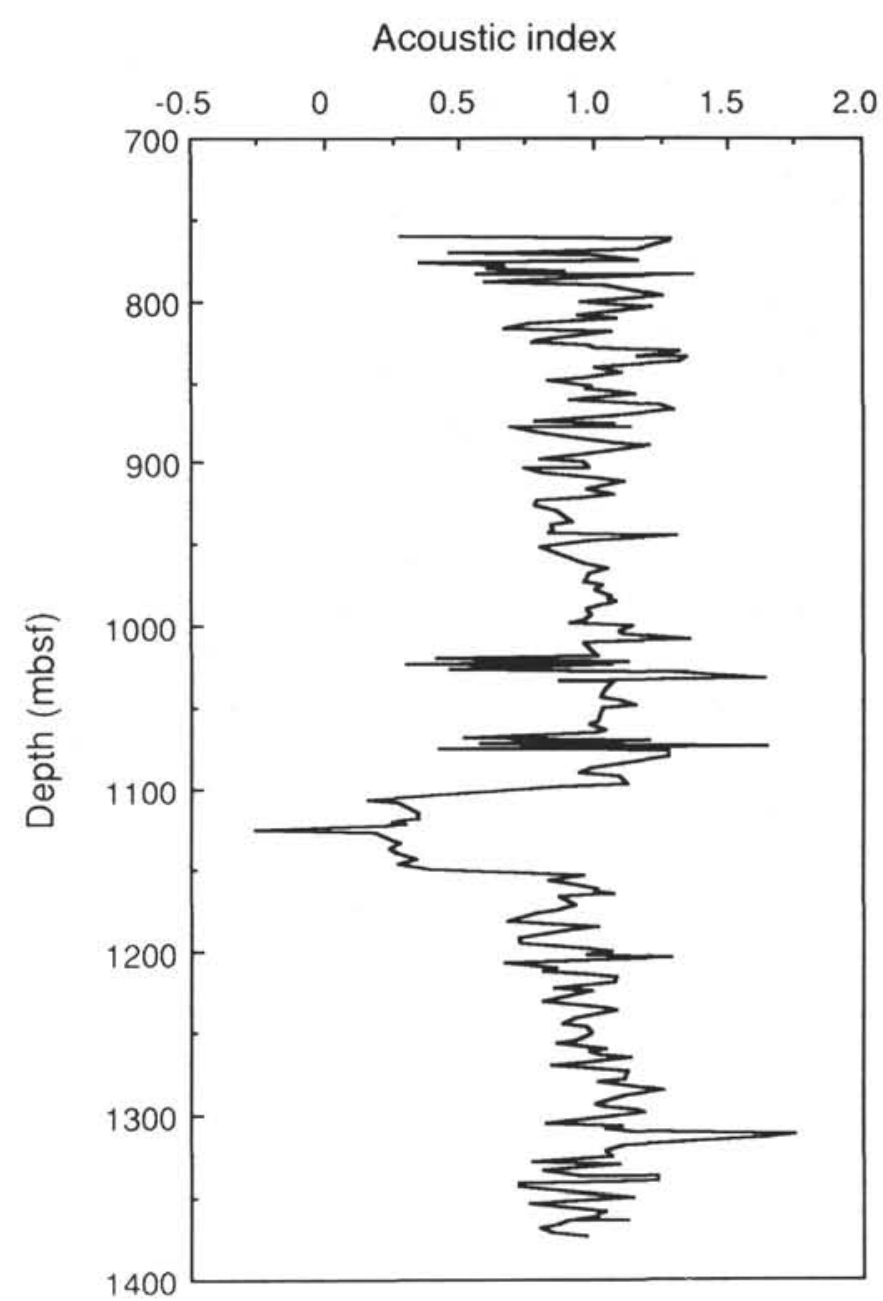

Figure 11. Acoustic index vs, depth in Unit V at Site 793.

Carey, S., and Sigurdsson, H., 1978. Deep-sea evidence for distribution of tephra from the mixed magma eruption of the Sourriere of St. Vincent, 1902: ash turbidites and air fall. Geology, 6:271-274.

Carlson, R. L., 1981. Acoustic properties of tuffaceous and calcareous sediments, Deep Sea Drilling Project Leg 60. In Hussong, D. M., Uyeda, S. et al., Init. Repts. DSDP, 60: Washington (U.S. Govt. Printing Office), 803-804.

Carlson, R. L., and Christensen, N. I., 1977. Velocities, densities, and elastic constants of basalt and trachytic tuff. DSDP Leg 39. In Perch-Nielsen, K., Supko, P. R., et al., Init. Repts. DSDP, 39: Washington (U.S. Govt. Printing Office), 493-496.

Carlson, R. L., Christensen, N. I., and Wilkens, R. H., 1980. Acoustic properties of volcaniclastic sediments recovered from the floor of the Philippine Sea, Deep Sea Drilling Project Leg 59. In Kroenke, L., Scott, R., et al., Init. Repts. DSDP, 59: Washington (U.S. Govt. Printing Office), 519-522.

Casagrande, A., 1936. Determination of preconsolidation load and its practical significance. Proc. Ist Conf. Soil Mech. Found. Eng. (Vol. 3). Am. Soc. Civ. Eng., 60-64.

Fisher, R. V., 1984. Submarine volcaniclastic rocks. In Kokelaar, B. P., and Howells, M. F. (Eds.), Marginal Basin Geology: Volcanic and Associated Sedimentary Processes in Modern and Ancient Basins. Spec. Publ., Geol. Soc. London, 16:5-28.

Hamilton, E. L., and Bachman, R., 1982. Sound velocity and related properties of marine sediments. J. Acoust. Soc. Am., 72:1891-1904.

Hill, P. R., and Marsters, J. C., 1990. Controls on physical properties of Peru continental margin sediments and their relationship to deformation styles. In Suess, E., von Huene, R., et al., Proc. ODP, Sci. Results, 112: College Station, TX (Ocean Drilling Program), 623-632. 
Jarrard, R. D., and Arthur, M. A., 1989. Milankovitch Paleoceanographic cycles in geophysical logs from ODP Leg 105, Labrador Sea and Baffin Bay. In Srivastava, S. P., Arthur, M., Clement, B., et al., Proc. ODP, Sci. Results, 105: College Station, TX (Ocean Drilling Program), 757-772.

Lisitzin, A. P., 1972. Sedimentation in the World Ocean, with Emphasis on the Nature, Distribution and Behavior of Marine Suspensions. Soc. Econ. Paleontol. Mineral., Spec. Publ., No. 17.

Lopatin, B. G., 1979. Petrography and petrochemistry of Miocene volcaniclastic sandstones (Hole 397). In von Rad, U., Ryan, W., et al., Init. Repts. DSDP, 47, Pt. 1: Washington (U.S. Govt. Printing Office), 699-702.

Lovell, M. A., 1984. Thermal conductivity and permeability assessment by electrical resistivity measurements in marine sediments. Mar. Geotechnol., 6:205-240.

1988. On the assessment of permeability and thermal conductivity in deep-sea clays by electrical and acoustic measurements. Geophys. Trans., 33:247-266.

McCoy, F. W., and Cornell, W., 1990. Volcaniclastic sediments in the Tyrrhenian Basin. In Kastens, K. A., Mascle, J., et al., Proc. ODP, Sci. Results, 107: College Station, TX (Ocean Drilling Program), 291-305.

Ogushwitz, P. R., 1985. Applicability of the Biot theory. III. Wave speeds versus depth in marine sediments. J. Acoust. Soc. Am., 77:453-463.

Pittenger, A., Taylor, E., and Bryant, W. R., 1989. The influence of biogenic silica on the geotechnical stratigraphy of the V-ring Plateau, Norwegian Sea. In Eldholm, O., Thiede, J., Taylor, E., et al., Proc. ODP, Sci. Results, 104: College Station, TX (Ocean Drilling Program), 923-940.

Pyle, D. M., 1989. The thickness, volume and grain size of tephra fall deposits. Bull. Volcanol., 51:1-15.
Skempton, A. W., 1970. The consolidation of clays by gravitational compaction. Q. J. Geol. Soc. London, 125:373-411.

Taylor, B., Fujioka, K., et al., 1990. Proc. ODP, Init. Repts., 126: College Station, TX (Ocean Drilling Program).

Wilkens, R., McLellan, P., Moran, K., Tribble, J. S., Taylor, E., and Verduzco, E., 1990. Diagenesis and dewatering of clay-rich sediments, Barbados accretionary prism. In Moore, J. C., Mascle, A., et al., Proc. ODP. Sci. Results, 110: College Station, TX (Ocean Drilling Program), 309-320.

Wilkens, R. H., and Handyside, T., 1985. Physical properties of equatorial Pacific sediments. In Mayer, L., Theyer, F., Thomas, E., et al., Init. Repts. DSDP, 85: Washington (U.S. Govt. Printing Office), 839-847.

Winsauer, W. O., Shearing, H. M., Jr., Masson, P. H., and Williams, M., 1952. Resistivity of brine saturated sands in relation to pore geometry. $A A P G$ Bull., 36:253-277.

Wohletz, K. H., 1983. Mechanisms of hydrovolcanic pyroclast formation: grain size, scanning electron microscopy, and experimental studies. $J$. Volcanol. Geotherm. Res., 17:31-63.

Wood, A. B., 1941. A Textbook of Sound: London (G. Bell).

Wyllie, M.R.J., Gardner, A. R., and Gardner, L. W., 1956. Elastic wave velocities in heterogenous and porous media. Geophysics, 21:41-70.

Date of initial receipt: 7 January 1991

Date of acceptance: 30 August 1991

Ms 126B-156 